\title{
Impact of New 5 Year Automobile Policy (2016-21) on the Profitability of Major Players in the Automobile Industry of Pakistan
}

\author{
Dr. Sadaf Mustafa, (Assistant Professor) \\ Rukhshinda Begum, (M.Phil Scholar) \\ Syeda Kanza Nisar, (Lecturer) \\ Ahmed Osama, (M.Phil Scholar)
}

Department of Commerce, University of Karachi, Pakistan

Doi:10.19044/esj.2018.v14n16p165 URL:http://dx.doi.org/10.19044/esj.2018.v14n16p165

\begin{abstract}
This research paper discusses the influence of new five year automobile policy announced by Economic Coordination Committee (ECC) in March 2016 for the period from 2016 to 2021 comparing with the old auto policy announced by the Government of Pakistan. The crucial point of this paper is to find the critical aspects of new auto policy and their impact on the profitability of major players in automobile industry of Pakistan. Main objectives of this policy are to help increase the volume with improved quality, catch the attention of investors, creating an extensive competitive environment, minimizing costs, technological improvement, satisfy all stakeholders through a Balance between tariffs and growth, customer satisfaction and Eliminating Monopoly of Existing Car Manufacturers. The important rationale of this paper is to have a look on the prevailing situation of automobile industry and the potential of this industry after the implementation of new auto-policy for 2016-21. It is to analyse whether this policy may influence profitability of the firms those have created their monopoly in this sector of Pakistan. The results of the study reveal that the profitability of major players of the automobile industry those were creating monopolies is not expected to decline even after the new policy. It may because of the trust of people on the local makes or expected ease in maintenance than those of the imported ones. However, the circumstances may change based on the customers' behavior that may cause the shift of their profit share to the New Entrants. Nevertheless, exploring the industrial alliance in this sector globally is of high importance for better quality, reasonable costs, fuel efficiency and striking designs. Various studies have been conducted to highlight the impacts of different policies announced by the
\end{abstract}


governments for automobile industry worldwide and for the Pakistan as well. Consequently, this study will be useful to seek out the probable challenges to confront in the automobile industry and to provide support for the future policies related to automobile companies and interrelated businesses like leasing, insurance, tracking and auto finance.

Keywords: Automobile Policy 2016-21, Competition, Consumer Welfare, Profitability

\section{Introduction}

Automobile industry of Pakistan is in front of new and imperative challenges. Prevailing era of Globalization demands trendy models, improved fuel efficiency, costs minimization, enhancement in user comfort for the survival and progress of the automobile industry of Pakistan. This competitive era also requires enhanced considerations towards safety and environment. Auto Industry is one of the emerging sectors of the Pakistan. Significant investments are being made for the development of assembly plants by the global manufacturers of automobile. Finding new and smart ways for value creation are supposed to be the key for prospering in the future. As per the Automotive Development Policy (2016-2021), a new manufacturer will need exceptional treatment with improved incentives to introduce and instigate its make, build up its standing, form a network for enhanced services and build up base for the part manufacturers.

Major areas of the Automotive Development Policy (2016-2021) as per the Board of Investment are being cited below:

There are two categories of New Investment as per the current policy. First one is the Category A named as the Greenfield Investment. This category calls for the installation of new automotive facilities by an investor for the production of automobiles those are not being assembled or manufactured in Pakistan.

Second one is the Category-B named as the Brownfield Investment. This category calls for revitalizing existing assembly and/or manufacturing facilities i.e. either not operational or closed since and before July 01, 2013 and the make is not being produced in Pakistan since then. This revitalization may be activated either by the original owners in independent capacity or by the new investors or through joint venture with foreign principal or by foreign principal in independent capacity through purchase of plant or various incentives for investment.

\section{Inclusion of New Entrants in the Automobile Industry of Pakistan}

The Ministry of Industry and Production allowed United Motors Private Limited, Kia-Lucky Motors Pakistan Limited and Nishat Group to set 
up units for assembly and manufacturing of vehicles under the Greenfield investment category, Ministry of Industries Secretary Khizar Hayat Gondal confirmed to The Express Tribune. (Source https://tribune.com.pk/story/1441350/three-companies-get-approval-set-carassembly-plants-pakistan/)

\section{Significance \& Background of the Auto Policy 2016-21}

Salient features of new auto policy 2016-21 as per the Board of Investment cover the duty-free import of plant $\&$ machinery to set up an assembly and manufacturing unit (on one-off basis), permission for the new investors to import 100 vehicles of the same option in form of CBUs at 50\% of the existing duty after the project gets initiated and reduction of $10 \%$ custom duty on non-localized parts for 5 years rather than earlier $32.5 \%$. The duty was reduced to $30 \%$ from July for existing investors. New investors are allowed to import localized parts at 25\% duty as compared to the current $50 \%$ for 5 years. For existing players, this duty on import of localized parts was decided to bring down to $45 \%$ from July 01, 2016.

Taken as a whole, the performance of Pakistan Automobile Sector remained unable to meet its true potential except for motor cycle manufacturing sector. Most of the Car assemblers are using technologies and providing insignificant features than those of the cars in Global Market. Domestic Consumers are not having the best available technologies and safety requirements in vehicles. Hence, Economic Coordination Committee (ECC) formulated the Automotive Development Policy (2016-21) for the development and growth of automobile industry in Pakistan.

\section{Objective and Scope of Research}

The objective of this study is to determine the role of the recent auto policy in minimizing the existing Monopoly thus enhancing the real growth of the economy of Pakistan. This study will be helpful to understand the upcoming challenges in the automobile industry of Pakistan and their probable impacts on the economy of Pakistan. It will also help develop the internal policies of automobile companies in order to come up with the expected challenges. It will also lend a hand to understand the auto industry after 5 years.

\section{Review of Related Literature}

Muhammad Jamil Afaqi \& Nadia Jahangir Seth has made an assessment of the SME Sector, its issues and challenges. They have considered the Automobile Sector as case point for the evolution in terms of Technology, Human Resources and the vision. 
The CSF study (2006) examines the motor-cycle industry in Pakistan and provides the reasons behind rapid growth in industry, problems being faced with respect to the value chain and the steps to be taken for further improvement. The problems faced by the motorcycle industry are the stagnant growth, higher taxes on locally manufactured motorcycles and high cost of locally manufactured components. They have provided solutions to come up with these obstacles through the provision of bank financing for purchase of motor cycles a sit available for other automobiles, R\&D Support to enhance export in this industry and the cost reduction ways.

Biswajit Nag, Saikat Banerjee \& Rittwik Chatterjee (2007) compare the production, trade and market share of automobile industry of various countries in Asia. This study makes an assessment of the growth in this industry and the role of the government in selected Asian Countries. It also makes a comparison of policy frameworks in these Asian countries

The Asian Development Bank (2008) conducted a study on the role of private sector in the various sectors of the economy of Pakistan including manufacturing, textiles, food \& beverages, fertilizers, cement and automobiles. The study observed that the automobile industry is mainly owned by the private sector. 18 automobile assembling units are set up as joint ventures and 47 units are engaged in production of motorcycles. The size of the industry is modest in terms of its contribution towards GDP and employment. Protection in the industry through various restrictions/ barriers left the same uncompetitive. Hence, ADB intervention was recommended for the identification of causes behind lower growth of the automobile industry and finding out the ways for improvement.

SME Development Report (2010-11) mentions the establishment of cluster project in Auto Industry and establishment of support centre for the development of tools for designing auto parts and testing facilities in Lahore and nearby areas. This facility was intended to provide the support to the vendors of auto parts for the development of auto industry.

M. Shahrukh Mirza and Irfan Anjum Manarvi (2011) present and analysis on the technological advancements in the Pakistan Automobile Car industry. This study reveals the benefits achieved by the Car assemblers and vendors through advancement in technology. Various recommendations are given for the betterment in the automobile industry of Pakistan. It is concluded in the study that the key factors for the progress in the industry include improved technology, affable policies of the government, interaction between academics and industry and R\&D.

Hafiz Pasha \& Zafar Ismail (2012) produced an analysis of the trends in Automotive Sector and Policy Framework. They also discussed the competitiveness assessment of this sector and degree of competitiveness in 
different segments of this sector including Cars, Motorcycles, Buses/ Trucks, tractors and manufacturers of auto parts.

IBA Working Paper No.01 (2012) studied the India-Pakistan trade in various sectors of the economy. For the automobile sector the study states that India has strong engineering base and considerable capacity of production. It further states that importing the components from China rather than other countries like Thailand will benefit the Pakistan in terms of cost and cluster in the industry will help reduce the cost of production.

IJCRB (2012) disclose the causes of failure of the automobile Industry in Pakistan through a case study on Revo car. It has made a detail assessment to find out the reasons for failure of this project. This paper covers a brief history of the industry, the IMC and existing demand \& supply conditions in the industry. The extent of the problems raised since the inception of the project was too high to be tackled and it got further enhanced by the time leaving the company unable to deal with the same in an appropriate manner. The price and quality issues in the project further created the survival issues that it could not compete the existing major players in the Automobile industry of Pakistan.

Muhammad Aqil, Seemab Qadeer, Dr. Rizwan Raheem Ahmed and Munawar Ali Qureshi (2014) discuss the protection and indigenization levels in the automobile industry of Pakistan from 1995 to 2005. According to this study, the automobile industry was not able to achieve the desired objectives set by the respective authorities and they consider the need for review the policy again for new and attainable objectives

CAR (2016) elaborates the material qualification in automobile industry. This paper explains the areas for reduction in material qualification. It further briefed the analysts' comments and opinions obtained by the team of CAR through interviews for the purpose to elaborate the material qualification process. This paper concludes that collaborative efforts are required for the introduction of new materials. This paper emphasizes the need for training in this area and advancement of technology for the growth and attainment of desired objectives.

Biswajit Nag (2016) discusses the future of automobile sector in between Pakistan \& India. It tries to help understand the normalization of trade in the automobile sector of both countries. As per the study, Indian auto industry is not assumed to have any considerable impact of the domestic industry of Pakistan. However, India may compete in those critical components in which Pakistan is a large importer.

Spearhead Analysis (2016) discusses that Pakistan with a rapidly growing population and increasing urbanization has an effervescent automobile market. There is a demand for all types of motor vehicles from the low to the high end. The availability of rather low-cost auto financing is further 
flourishing this ever-expanding market. Imports continue to play a significant role in the local market while there is a developed manufacturing base for vehicles. This study explains the rationale behind spending billions on the import of vehicles in a country that has three major manufacturing units, producing a diverse range of vehicles, and where the government is making hectic efforts to attract foreign investors. This study further states that the import of vehicles is a non-productive activity i.e. leading to outflow of foreign exchange and is opposed to avail productive revenue-generating options locally. With the growing population base and limited growth opportunities in the manufacturing sector, Pakistan needs to focus on developing its local industry and the automobile sector, through joint efforts for the viable economic growth. Sustainability of the policy framework is also an issue however. It is to be said that in the past if the Government does not show the proper implementation of these policies and give in to pressure from vested stakeholders, the whole proposed structure might come crashing down. The opportunity is there and it is attainable. The government needs to step forward and implement it for the long-term capability of the sector and the country.

Vaqar Ahmed \& Samavia Batool (2017) explains the trade between in India \& Pakistan with the perspective of Automobile Industry. This study covers the obstacles, competitive, economic standings, investment policies and trade regulation between both countries. This study reflects that the three major players in the Automobile Industry of Pakistan are Toyota, Honda and Suzuki that have contributed in the Total Market Share.

CAR (2017) studies the benefits of NAFTA for the automobile industry and results for withdrawal from the same. It reveals that such withdrawal will result in the higher cost of production and unattractive return on investments.

Avinandan Mukharjee and Trilochan Sastry (1996) produced a comparison of automobile industries of developing economies of Brazil, Korea, India and China. Comparison reveals Korea to be the fastest growing in this sector due to the extensive support of government and enhanced research and developments in this area.

Yuan Chen, C.-Y. Cynthia Lin Lawell, and Yunshi Wang (2017) described the influence of government policies on the automobile industry of China. They particularly addressed the impacts of demand and supply of automobiles with respective policies of the government to analyze the reasons for growth in automobile industry of China and concluded significant results that may help out in developing important policies for this industry. Luo, Jianxi (2017) also discussed the impact of government policies on the industrial progress with special consideration to automotive industry in China and found strong relationship in the same. 
Caroline Rodrigues Vaz, Tania Regina Shoeninger Rauen and Álvaro Guillermo Rojas Lezana (2017) provide some important dimensions for the automobile industry focusing on the innovation and sustainability in this sector. This study is based on the twelve years' literature beginning from 2004 up till 2016. Results of the study suggest that marginal innovations are not very expensive. However, major innovations are necessary for bringing down negative impacts on environment and the development of this sector.

\section{Hypothesis}

H1: There is a positive effect of the current five year auto-policy on the profitability of Major Players in the Automobile Industry of Pakistan

$\mathrm{H} 2$ : There is negative effect of the current five year auto-policy on the profitability of Major Players in the Automobile Industry of Pakistan H0: There is no effect of the current five year auto-policy on the profitability of Major Players in the Automobile Industry of Pakistan

\section{Research Methodology}

This study analyses positive and negative aspects of recent automobile policy as compared to previous policy. The sample period for this study is 6 years i.e. from 2012 till 2017 because the first automobile policy was announced in 2008 and second policy was announced in 2016. Hence, annual reports of three major players in automobile industry of Pakistan are to be taken for the study. The detail mentioned in this paper is based on the Financial Statements of the Automobile Companies and the comprehensive review of literature related to automobile industry and its policies.

\section{Analysis}

Sales, Net Profit Margin, Gross Profit Margin along with the administrative and distribution costs from 2012 to 2017 were analyzed for three major players of automobile industry including Honda Atlas, Indus Motor Company and Pak Suzuki. Appended below are the briefings of analysis.

\section{Honda Atlas}

Appended below is the position of Key performance indicators of Honda Atlas Company. 
Sales

Cost of Sales GP

Profit after Tax

NPM Per Year

Variation in Annual NPM

Distribution Expenses as $\%$ of Sales

Administrative

Expenses as \% of Sales

GP Margin Per Year COGS as a $\%$ of Sales

\begin{tabular}{|c|c|c|c|c|c|}
\hline \multicolumn{6}{|c|}{ Honda Atlas } \\
\hline 2012 & 2013 & 2014 & 2015 & 2016 & 2017 \\
\hline $38,011,857.00$ & $42,325,242.00$ & $44,878,713.00$ & $45,772,177.00$ & $55,022,415.00$ & $64,534,021.00$ \\
\hline $35,235,893.00$ & $38,646,049.00$ & $40,253,929.00$ & $41,098,571.00$ & $49,376,506.00$ & $57,754,987.00$ \\
\hline $2,775,964.00$ & $3,679,193.00$ & $4,624,784.00$ & $4,673,606.00$ & $5,645,909.00$ & $6,779,034.00$ \\
\hline $1,204,109.00$ & $1,607,804.00$ & $2,001,560.00$ & $2,350,891.00$ & $3,001,799.00$ & $3,752,479.00$ \\
\hline $3.17 \%$ & $3.80 \%$ & $4.46 \%$ & $5.14 \%$ & $5.46 \%$ & $5.81 \%$ \\
\hline & $0.63 \%$ & $0.66 \%$ & $0.68 \%$ & $0.32 \%$ & $0.36 \%$ \\
\hline 3 & 3 & 3 & 3 & 3 & 3 \\
\hline 1 & 1 & 1 & 1 & 1 & 1 \\
\hline $7 \%$ & $9 \%$ & $10 \%$ & $10 \%$ & $10 \%$ & $11 \%$ \\
\hline $93 \%$ & $91 \%$ & $90 \%$ & $90 \%$ & $90 \%$ & $89 \%$ \\
\hline
\end{tabular}

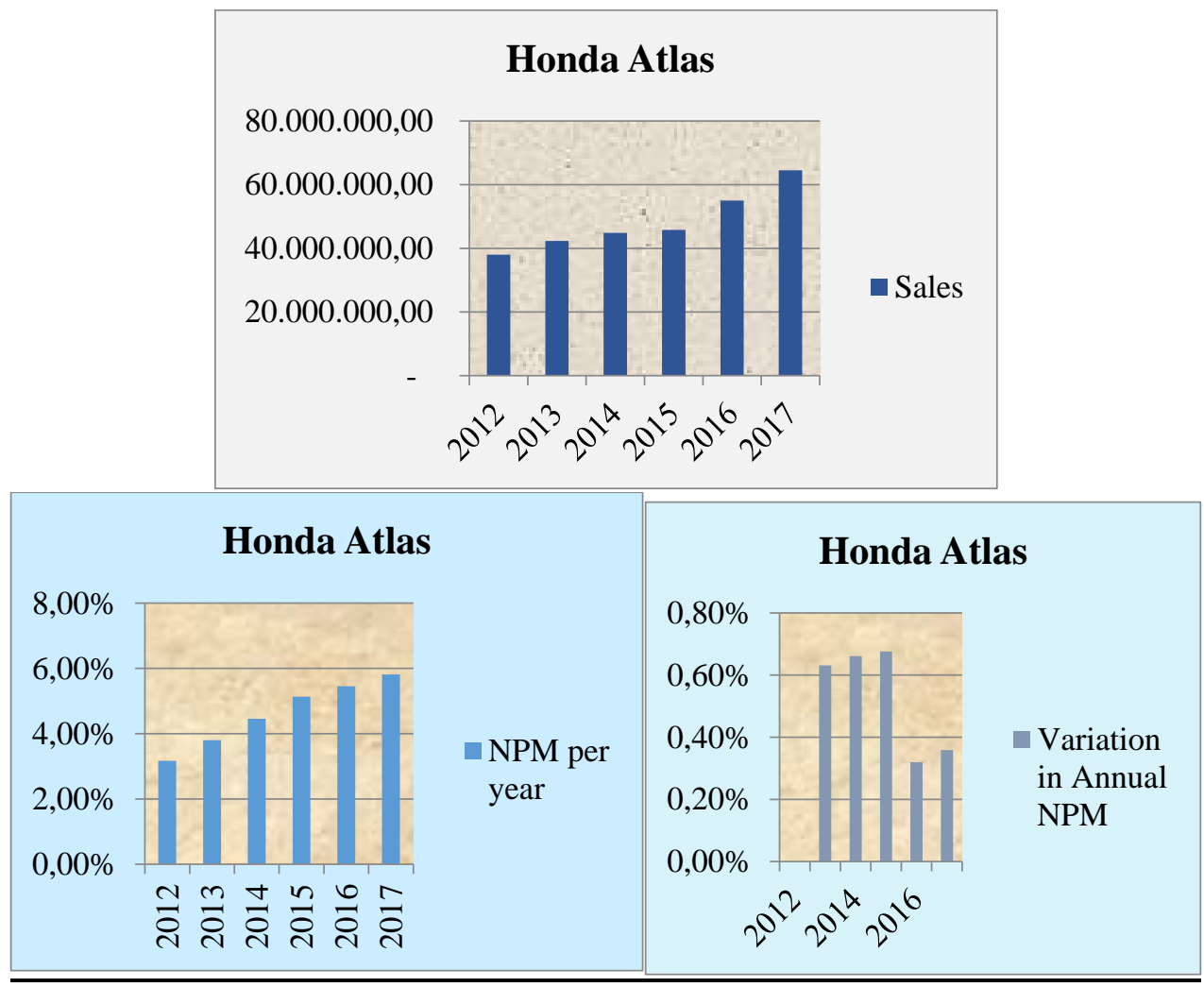




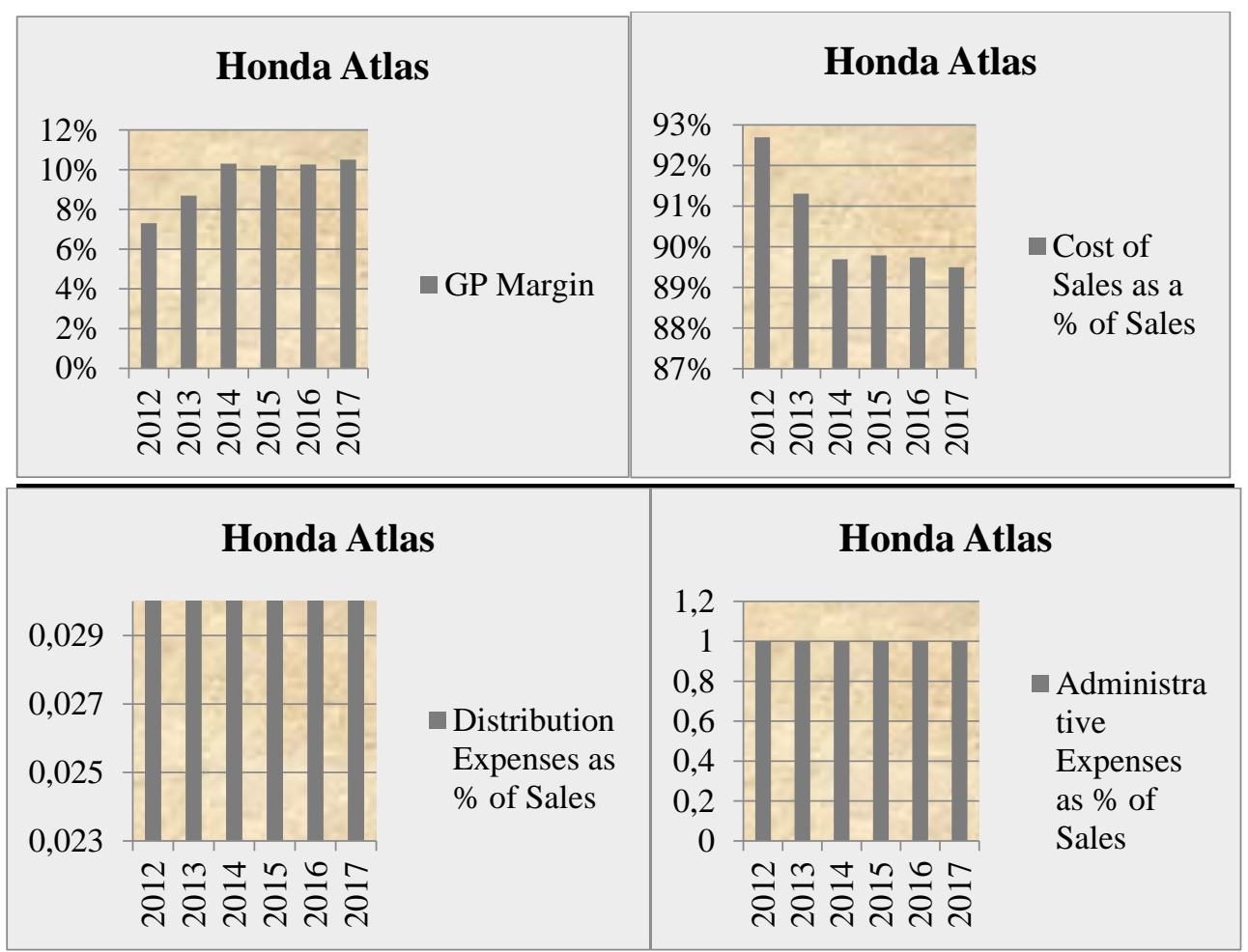

Source: Annual Reports of the Company

\section{Analysis}

According to the position reflected above, Sales and Net Profit Margins of Honda Atlas increased in 2016. However, percentage of increase that declined in 2016 again showed a rise in 2017. Gross Profit Margin also showed rise in 2017 with decreased cost of sales. No impact on distribution and administrative expenses as a percentage of sales was observed during the whole tenure taken into consideration

\section{Indus Motor Company (Toyota)}

Sales

Cost of Sales GP

Profit after

Tax

NPM Per Year

Variation in

Annual NPM

Distribution

Expenses as \% of Sales

\begin{tabular}{|c|c|c|c|c|c|}
\hline \multicolumn{7}{|c|}{ Indus Motor Company } \\
\hline 2012 & 2013 & 2014 & 2015 & 2016 & 2017 \\
\hline $76,962,642.00$ & $63,829,075.00$ & $57,064,000.00$ & $96,516,000.00$ & $108,759,000.00$ & $112,271,656.00$ \\
\hline $70,400,788.00$ & $57,972,038.00$ & $51,270,000.00$ & $82,272,000.00$ & $91,027,000.00$ & $92,449,955.00$ \\
\hline $6,561,854.00$ & $5,857,037.00$ & $5,794,000.00$ & $14,244,000.00$ & $17,732,000.00$ & $19,821,701.00$ \\
\hline & & & & & \\
$4,302,715.00$ & $3,357,545.00$ & $3,873,000.00$ & $9,110,000.00$ & $11,455,000.00$ & $13,001,265.00$ \\
\hline $5.59 \%$ & $5.26 \%$ & $6.79 \%$ & $9.44 \%$ & $10.53 \%$ & $11.58 \%$ \\
\hline & $-0.33 \%$ & $1.53 \%$ & $2.65 \%$ & $1.09 \%$ & $1.05 \%$ \\
\hline 1 & & & & & 1 \\
\hline
\end{tabular}




\begin{tabular}{c|c|c|c|c|c|c|}
$\begin{array}{c}\text { Administrative } \\
\text { Expenses as } \% \\
\text { of Sales }\end{array}$ & 1 & 1 & 1 & 1 & 1 & 1 \\
\cline { 2 - 7 } $\begin{array}{c}\text { GP Margin } \\
\text { Per Year }\end{array}$ & $9 \%$ & $9 \%$ & $10 \%$ & $15 \%$ & $16 \%$ & $18 \%$ \\
\cline { 2 - 7 } $\begin{array}{c}\text { COS a } \% \\
\text { of Sales }\end{array}$ & $91 \%$ & $91 \%$ & $90 \%$ & $85 \%$ & $84 \%$ & $82 \%$ \\
\hline
\end{tabular}
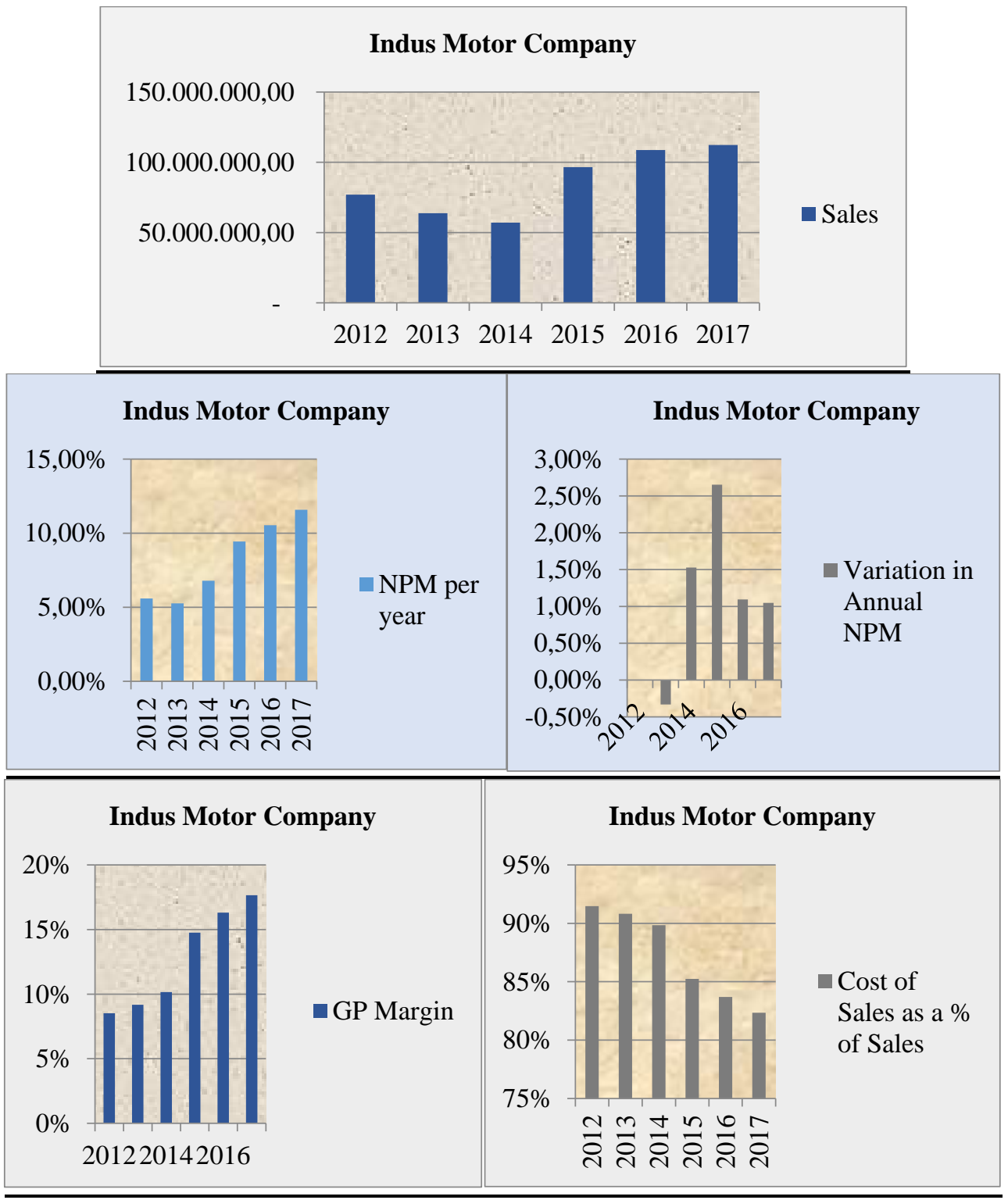


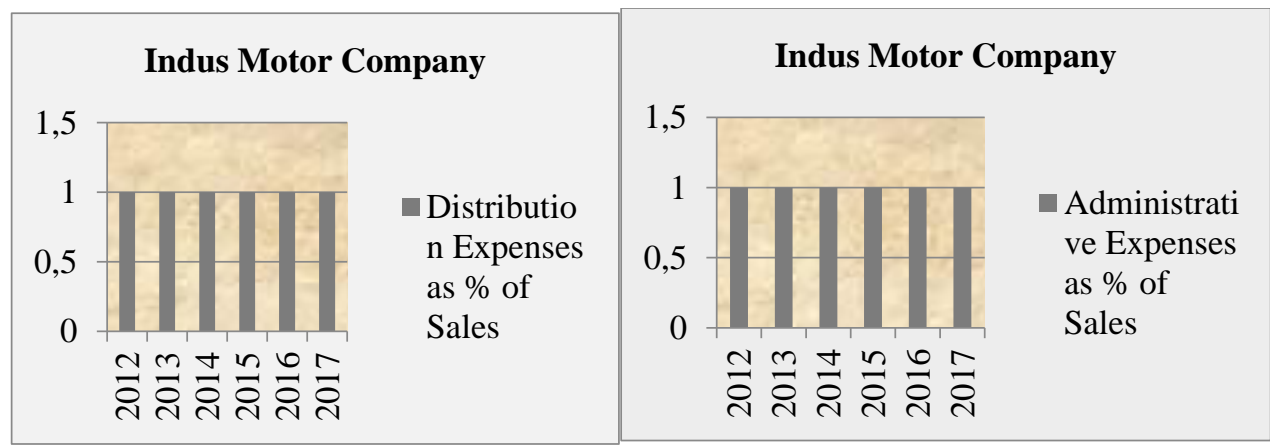

Source: Annual Reports of the Company

\section{Analysis}

According to the position reflected above, Sales and Net Profit Margins of Indus Motor Company increased in 2016. However, percentage of increase that declined in 2016 again showed a rise in 2017. Gross Profit Margin also showed rise in 2017 with decreased cost of sales. No impact on distribution and administrative expenses as a percentage of sales was observed during the whole tenure taken into consideration.

\section{Pak Suzuki}

Appended below is the position of Key performance indicators of Pak Suzuki Company.

\begin{tabular}{|c|c|c|c|c|c|c|}
\hline & \multicolumn{6}{|c|}{ Pak Suzuki } \\
\hline & 2012 & 2013 & 2014 & 2015 & 2016 & 2017 \\
\hline Sales & $58,531,137.00$ & $51,061,333.00$ & $53,664,947.00$ & $84,548,757.00$ & $76,516,040.00$ & $101,811,611.00$ \\
\hline Cost of Sales & $56,185,397.00$ & $47,818,820.00$ & $49,481,248.00$ & $73,061,309.00$ & $69,167,463.00$ & $92,159,038.00$ \\
\hline GP & $2,345,740.00$ & $3,242,513.00$ & $4,183,699.00$ & $11,487,448.00$ & $7,348,577.00$ & $9,652,573.00$ \\
\hline $\begin{array}{c}\text { Profit after } \\
\text { Tax }\end{array}$ & $978,022.00$ & $1,849,357.00$ & $1,921,894.00$ & $5,842,671.00$ & $2,772,635.00$ & $3,825,821.00$ \\
\hline NPM Per Year & $1.67 \%$ & $3.62 \%$ & $3.58 \%$ & $6.91 \%$ & $3.62 \%$ & $3.76 \%$ \\
\hline $\begin{array}{c}\text { Variation in } \\
\text { Annual NPM }\end{array}$ & & $1.95 \%$ & $-0.04 \%$ & $3.33 \%$ & $-3.29 \%$ & $0.13 \%$ \\
\hline $\begin{array}{l}\text { Distribution } \\
\text { Expenses as \% } \\
\text { of Sales }\end{array}$ & 1 & 1 & 1 & 2 & 3 & 3 \\
\hline $\begin{array}{l}\text { Administrative } \\
\text { Expenses as \% } \\
\text { of Sales }\end{array}$ & 1 & 2 & 2 & 1 & 2 & 2 \\
\hline $\begin{array}{l}\text { GP Margin } \\
\text { Per Year }\end{array}$ & $4 \%$ & $6 \%$ & $8 \%$ & $14 \%$ & $10 \%$ & $9 \%$ \\
\hline $\begin{array}{c}\text { COGS as a \% } \\
\text { of Sales }\end{array}$ & $96 \%$ & $94 \%$ & $92 \%$ & $86 \%$ & $90 \%$ & $91 \%$ \\
\hline
\end{tabular}




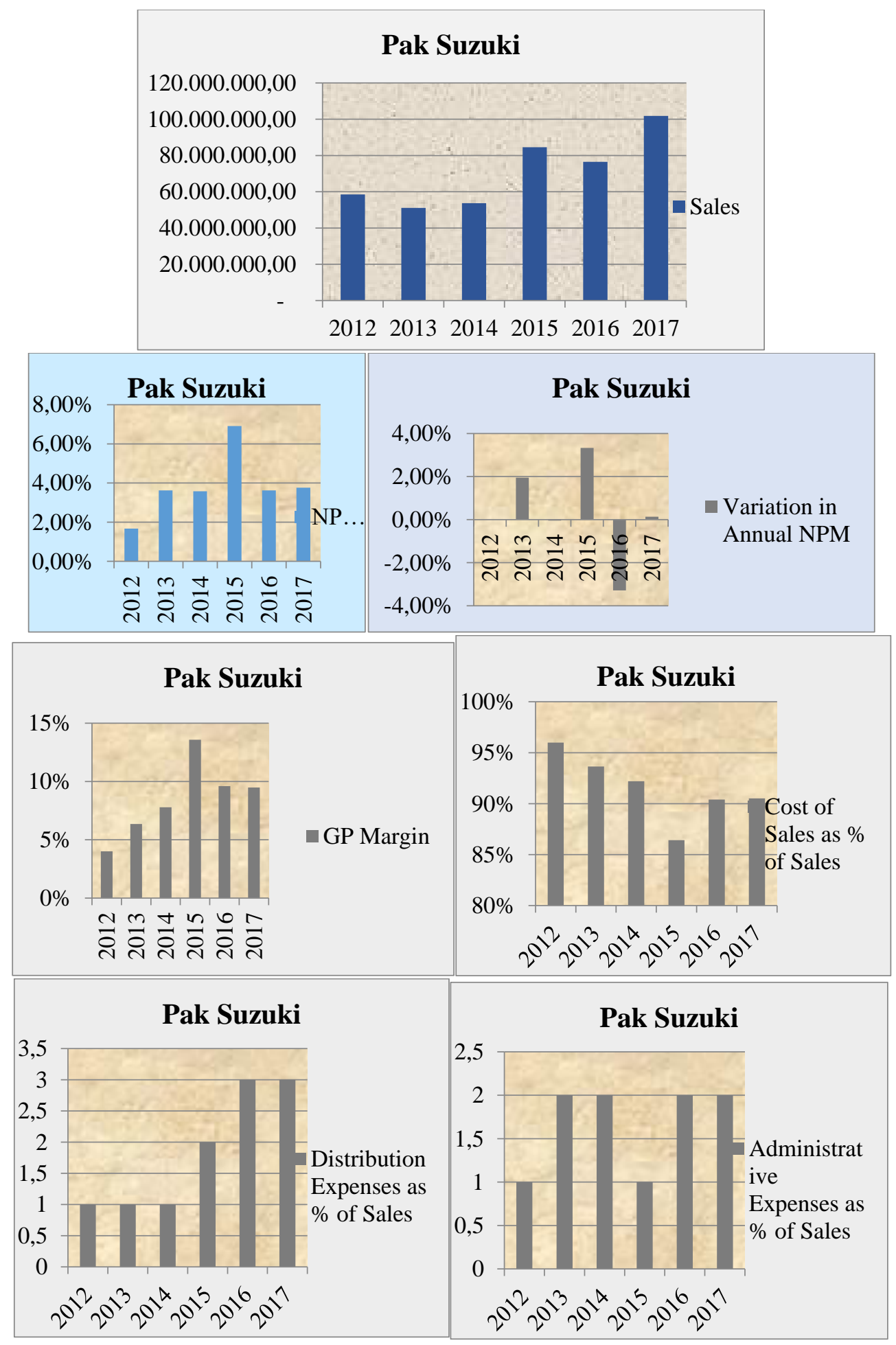

Source: Annual Reports of the Company 


\section{Analysis}

According to the position reflected above, Sales of Pak Suzuki showed a decline in 2016. However, the same again increased in 2017. Though, cost of sales, administrative and distribution costs as percentage of sales increased in 2017, however, Net profit margin still showed increase.

\section{Conclusion \& Suggestions}

It is reflected from the above analysis that Sales and Profit Margins of two of the above major players increased with a lower percentage in 2016 from those of the previous years' whereas one is showing the considerable decline just after the implementation of Recent 5 year automobile policy in 2016. However, all the companies showed positive movement in sales and net profit margin in 2017 again. Besides, Sales of all three companies showed continuous rise from 2012 to 2017 even after the policy changes. Hence, it may be concluded that the share of profit of the major players of the automobile industry those were creating monopolies is not expected to decline even after the new policy. It may because of the trust of people on the local makes or expected ease in maintenance than those of the imported ones. However, the circumstances may change based on the customers' behavior that may cause the shift of their profit share to the New Entrants.

In view of the above, it is suggested to continue the relaxation provided in recent policy on the import of automobiles and benefits for the Foreign Investors in order to encourage better quality at relatively lower costs automobiles. Though, this policy is not showing to effect monopoly of existing car manufacturers in the near future, however, consistent implementation of policy may change the scenario.

\section{Limitations}

The above study is limited to the data collected and the time restraints. Moreover, resources required to proceed with the research procedure are scared i.e. limited financial resources, accessibility to the desired personnel in data collection.

\section{References:}

1. Afaqi, M. J., \& Seth, N. J. (2007). SME Sector, Genesis, Challanges \& Prospects. Islamabad: SMEDA.

2. Ahmed, V., \& Batool, S. (n.d.). India-Pakistan Trade: Perspective from the Automobile Sector in Pakistan. In N. Taneja, I. Dayal, N. Taneja, \& I. Daniyal (Eds.), India-Pakistan Trade Normalization, The Unfinished Economic Agenda. New Delhi, India: Springer Nature.

3. Analysis, $\mathrm{S}$. (2016). http://spearheadresearch.org/index.php/category/researchopinions/e 
cofin. Retrieved from spearheadresearch.org: http://www.spearheadresearch.org

4. Analysis, $\mathrm{S}$ (2016). http://spearheadresearch.org/index.php/category/researchopinions/e cofin. Retrieved from spearheadresearch.org: http://www.spearheadresearch.org

5. Aqil, M., Qadeer, S., Ahmed, D. R., \& Qureshi, M. A. (2014). PROTECTION AND INDIGENIZATION LEVELS IN PAKISTAN AUTOMOBILE INDUSTRY FROM 1995 TO 2005. International Journal of Engineering \& Scientific Research, Vol.2(Issue 4), 1-12.

6. Bank, T. A. (2008). Private Sector Assessment Pakistan. Pakistan: The Asian Developement Bank.

7. Chen, Y., Lin Lawell, C.-Y. C., \& Wang, Y. (2017). The Chinese Automobile Industry and Government Policy.

8. Fund, C. S. (2006). Policy Analysis on the Competitive Advantage of the Motorcycle Industry in Pakistan; Problems and Prospects. Islamabad: USAID \& Ministry of Finance Govt of Pakistan.

9. Hussain, I. (2012, September). PROSPECTS, CHALLENGES AND RISKS FOR INCREASING INDIA-PAKISTAN TRADE. IBA Working Paper Series, pp. 1-39.

10. Jaffery, A. A., \& Mansoor, A. (2016). Competitive Analysis of Auto Sector in Pakistan and China.

11. Jianxi, L. a. (n.d.). The impact of government policies on industrial evolution : the case of China's automotive industry. Retrieved from http://hdl.handle.net/1721.1/38511

12. Khan, M. R., \& Ahmad, Y. (2012). FAILURE OF AUTOMOBILE MANUFACTURING IN PAKISTAN-A CASE OF THE REVO CAR. INTERDISCIPLINARY JOURNAL OF CONTEMPORARY RESEARCH IN BUSINESS, VOL 4(No. 4), 1-16.

13. Mirza, M. S., \& Manarvi, I. A. (2011). Analysis of Technological advancements in Pakistani Automobile Car Industry. Global Journal of Research in Engineering, Volume 11(Issue 3), 1-16.

14. Modi, S. (2016). Material Qualification in the Automotive Industry. Centre for Automotive Research.

15. Mukherjee, A., \& Sastry, T. (1996). The Automotive Industry in Emerging Economies:A Comparison of Korea, Brazil, China and India. Ahmedabad, India: Indian Institute of Management, Ahmedabad 380015, India.

16. Nag, B. (2016). Assessing the Future of Trade in the Automobile Sector between India and Pakistan: Implications of Abolishing the Negative List. New Delhi, India: Indian Institute of Foreign Trade New Delhi India. 
17. Nag, B., Banerjee, S., \& Chatterjee, R. (2007). Changing Features of the Automobile Industry in Asia: Comparison of Production, Trade and Market Structure in Selected Countries. Asia-Pacific Research and Training Network on Trade Working Paper Series, No. 37, July 2007, $1-47$.

18. Pasha, H., \& Ismail, Z. (2012). An Overview of Trends in the Automotive Sector and the Policy Framework. International Growth Centre.

19. Policy, A. D. (n.d.). Automotive Developement Policy (ADP) 2016-21.

20. Program, A. I. (2008). Ministry of Industries, Production and Special Initiatives, Government of Pakistan.

21. Research, C. o. (2017, January). Trade benefits to the automotive industry and potential consequences of withdrawal from the agreement. NAFTA BRIEFING, pp. 1-19.

22. Small \& Mediun Enterprise Developement Authority, G. o. (2011). SME Developement Report (2010-2011), Programmes \& Initiatives. Lahore: Small \& Mediun Enterprise Developement Authority, Governmrnt of Pakistan.

23. SMEDA, IMC, Suzuki, P., \& Toyota. (2012 - 2016). Annual Reports Automobile Companies.

24. Vaz, C. R., Shoeninger Rauen, T. R., \& Rojas Lezana, Á. G. (2017). Sustainability and Innovation in the Automotive Sector: A Structured Content Analysis. MDPI. 